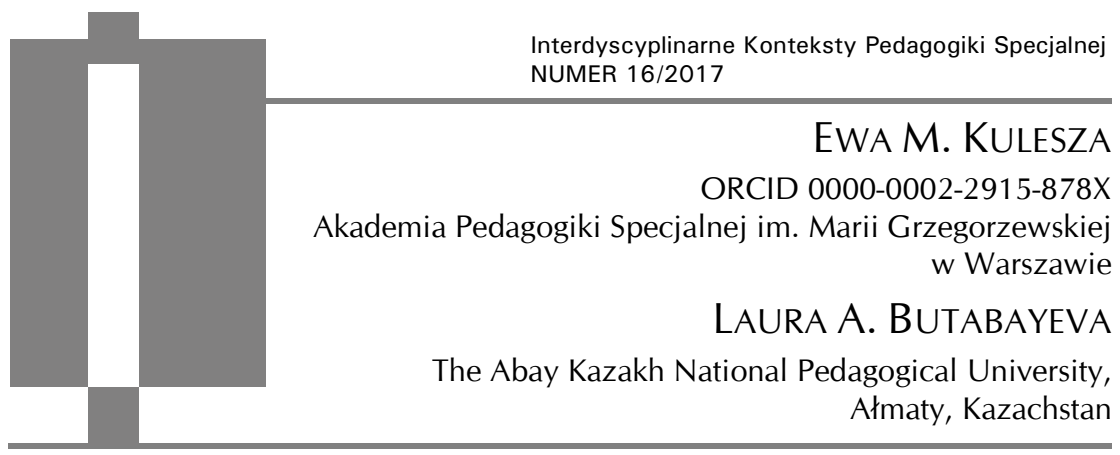

\title{
Osoba z niepełnosprawnością w rozmowach kazachskich rodziców z dziećmi ${ }^{1}$
}

Abstract: Ewa M. Kulesza, Laura A. Butabayeva, Osoba z niepetnosprawnościa $w$ rozmowach kazachskich rodziców $z$ dziećmi [Person with disability in the talks of Kazakh parents with children]. Interdyscyplinarne Konteksty Pedagogiki Specjalnej, nr 16, Poznań 2017. Pp. 207-228. Adam Mickiewicz University Press. ISSN 2300-391X

The paper presents the issue of social transmission by Kazakh parents concerning disability, especially their knowledge of disability and content of conversations with their children. Diagnostic survey method, survey technique and the author's questionnaire with open-ended questions were used. The analysis of content of the written statements shows that the parental message in the inclusive group compared to the general population more strongly emphasizes the attitude of tolerance and nondiscrimination of the disabled peer. Research confirms the impact of social context on the knowledge, attitudes and the image of a person with a disability and these results are consistent with those of other authors.

KEY WORDS: person with a disability, inclusive school, mainstream school, children, parents

${ }^{1} \mathrm{~W}$ artykule przedstawiono fragment badań prowadzonych przez Laurę A. Butabayevę w Kazachstanie pod kierunkiem Ewy M. Kuleszy i przedstawionych w nieopublikowanej rozprawie pt. „Atrakcyjność społeczna rówieśnika z niepełnosprawnością w wypowiedziach uczniów klas pierwszych kazachskich szkól”, Archiwum Akademii Pedagogiki Specjalnej im. Marii Grzegorzewskiej, Warszawa 2016. 


\section{Wstęp}

Społeczny obraz i nastawienie wobec osób z niepełnosprawnością uwarunkowane są wieloma czynnikami. Do ważniejszych badacze zaliczają rodzaj i stopień niepełnosprawności lub choroby, zwłaszcza zewnętrzne objawy (cechy fizyczne i zachowanie), właściwości środowiska społecznego, w tym kulturę, tradycje, przekonania, stereotypy, dominujące idee 2 .

Już w latach 60. XX w. stwierdzono eksperymentalnie, że dużą rolę $\mathrm{w}$ kształtowaniu pozytywnego nastawienia do drugiej osoby odgrywają tzw. czynniki ekologiczne - dystans i częstotliwość spotkań: im mniejsza jest odległość między ludźmi i częściej człowiek widzi jakąś twarz, tym bardziej wydaje mu się ona pociągająca ${ }^{3}$. Duże znaczenie ma więc bezpośrednie doświadczenie w obcowaniu $\mathrm{z}$ inną osobą. Taki osobowy kontakt wpisany jest $\mathrm{w}$ ideę integracji, która obecna w polskiej przestrzeni społecznej od wczesnych lat 90. wywarła silny wpływ na podejście do osób z niepełnosprawnością, radykalnie zmieniła politykę społeczno-oświatową państwa polskiego, sprawiła, że osoby $\mathrm{z}$ niepełnosprawnością przekroczyły granice "swoich rezerwatów” i coraz częściej są obecne we wspólnej przestrzeni publicznej. Przegląd polskich badań wykazał m.in.:

- wzrost wskaźnika kontaktów dorosłych Polaków z osobami z niepełnosprawnością: $24 \% \mathrm{w}$ latach $70 ., 40 \%$ pod koniec lat 90. i ok. $60 \%$ w 2013 r. ;

2 Stereotypy niepetnosprawności. Między wykluczeniem a integracja, red. M. Chodkowska i in., UMCS, Lublin 2010; I. Chrzanowska, Pedagogika Specjalna. Od tradycji do wspótczesności, Oficyna Wydawnicza „Impuls”, Kraków 2015; E. Czykwin, Stygmat społeczny, Wydawnictwo Naukowe PWN, Warszawa 2007; G. Durka, Stereotypy i uprzedzenia wobec osób niepetnosprawnych, [w:] W kręgu niepetnosprawności - teoretyczne i praktyczne aspekty poszukiwań w pedagogice specjalnej, red. T. Żółkowska, L. Konopska, Wydawnictwo Uniwersytetu Szczecińskiego., Szczecin 2009; S. Olszewski, K. Parys, M. Trojańska, Przestrzenie życia osób z niepetnosprawnościa, Wydawnictwo Naukowe Uniwersytetu Pedagogicznego, Kraków 2012.

${ }^{3}$ R. Zaions, Attitudinal effects of mere exposure, "Journal of Personality and Social Psychology" 1968, Vol. 9.

${ }^{4}$ A. Ostrowska i in., Niepetnosprawni w społeczeństwie 1993-2013, Wydawnictwo IFiSPAN, Warszawa 2015. 
- zwiększającą się liczbę Polaków twierdzących, że osoby z niepełnosprawnością, tak jak osoby pełnosprawne, winny się uczyć, pracować i mieć wszelkie prawa do czerpania satysfakcji z życia5;

- powielanie przez media stereotypowego obrazu osoby z niepełnosprawnością, prezentujące ją jako bohatera, którego należy podziwiać albo jako osobę bezradną, godną współczucia, potrzebującą pomocy innych. Ta druga charakterystyka dominuje w mediach ${ }^{6}$;

- zróżnicowane postawy nauczycieli wobec osób z dysfunkcjami: od współczucia, litości i bezradności (większość) do niesienia pomocy, akceptacji i szacunku (mniej niż połowa)7;

- przyznanie osobom z niepełnosprawnością prawa do bycia szczęśliwymi przez zdecydowaną większość pedagogów specjalnych";

- podział nauczycieli szkół masowych na tych, którzy są doświadczeni i entuzjastyczni i opowiadają się za integracją i tych, którzy są zagubieni i obojętni i obawiają się integracji ${ }^{9}$;

- najmniej przychylne nastawienia dorosłych Polaków wobec osób z niepełnosprawnością intelektualną, niepełnosprawnością sprzężoną (np. intelektualną i ruchową) i bardzo widocznymi w pierwszym kontakcie zniekształceniami twarzy, deformacjami tułowia, kończyn dolnych i górnych10;

${ }^{5}$ Stereotypy niepetnosprawności...; E. Czykwin, op. cit.; G. Durka, op. cit.

${ }^{6}$ I. Banach, Od integracji do inkluzji, Oficyna Wydawnicza Uniwersytetu Zielonogórskiego, Zielona Góra 2014.

7 Cz. Kosakowski, Węzłowe problemy pedagogiki specjalnej, Wydawnictwo Akapit, Toruń 2003.

${ }^{8}$ M. Skura, Postawy nauczycieli szkoły specjalnej wobec osób z niepetnosprawnościa, „Szkoła Specjalna”, 2015,1, s.43-44.

9 K.A. Tersa, Rola Innego w rozwoju szkoty i nauczyciela. O potencjale tolerancji wobec niepetnosprawnych, [w:] Tolerancja a edukacja, red. M. Patalon, Wydawnictwo Uniwersytetu Gdańskiego, Gdańsk 2008.

${ }^{10}$ A. Sękowski, Tendencje integracyjne a postawy wobec osób niepetnosprawnych, [w:] Pedagogika specjalna w reformowanym ustroju edukacyjnym. Materiały z Ogólnopolskiej Konferencji Naukowej, Kazimierz Dolny, 25-26 maja 2000, red. Z. Palak, Wydaw- 
- tworzenie przez większość dzieci w wieku wczesnoszkolnym obrazu osoby z niepełnosprawnością jako tej, która ma widoczne dysfunkcje narządu ruchu, najczęściej jest na wózku inwalidzkim lub z kulami czy laską ${ }^{11 ;}$

- decydujący wpływ cech fizycznych na niekorzystną ocenę osoby z niepełnosprawnością przez dzieci w wieku wczesnoszkolnym ${ }^{12}$;

- większą skłonność dzieci dziesięcioletnich niż dzieci sześcioletnich do nawiązania interakcji z osobą z dysfunkcjąi3;

- korzyści z celowo organizowanych zajęć w grupach integracyjnych, a w szczególności wzbogacenie wiedzy dzieci o niepełnosprawności oraz nabycie przez nich nowych umiejętności społecznych14;

- większą wiedzę o niepełnosprawności rodziców uczniów pełnosprawnych uczących się w placówkach integracyjnych oraz ich bardziej pozytywne postawy wobec osób z niepełnosprawnością niż rodziców uczniów ze szkół masowych ${ }^{15}$.

nictwo UMCS, Lublin 2001; B. Jachimczak, Postawy wobec niepetnosprawności - szansa na społeczna akceptację, [w:] Pedagogika specjalna - koncepcje i rzeczywistość, red. T. Żółkowska, Print Group, Szczecin 2007.

11 E.M. Kulesza, Definiowanie pojęcia osoba niepetnosprawna przez uczniów klas pierwszej i trzeciej szkoły ogólnodostępnej, [w:] Edukacja w warunkach zmiany społecznej i kulturowej, red. E. Skrzetuska, M. Jurewicz, Wydawnictwo SGGW, Warszawa 2016, s. 113-127.

12 A. Soroka-Fedorczuk, Osoby niepetnosprawne w opiniach dzieci, Oficyna Wydawnicza „Impuls”, Kraków 2007.

13 Ibidem.

${ }^{14}$ D. Al-Khamisy, Edukacja przedszkolna a integracja społeczna, Wydawnictwo Akademickie "Żak”, Warszawa 2006; B. Oszustowicz, Obraz osoby niepetnosprawnej w świadomości dzieci sześcioletnich z przedszkolnej grupy integracyjnej, [w:] Integracja społeczna osób niepetnosprawnych, red. G. Dryżałowska, H. Żuraw, Wydawnictwo Akademickie "Żak", Warszawa 2004; J. Smogorzewska, G. Szumski, Rozwijanie kompetencji społecznych dzieci przedszkolnych. Teoria-Metodyka-Efekty, PWN, Warszawa 2015.

${ }^{15}$ M. Sekułowicz, Integracja przedszkolna dzieci a postawy rodziców wobec osób niepetnosprawnych, [w:] Pedagogika specjalna szansa na realizacje potrzeb osób niepetnosprawnych, red. W. Dykcik, C. Kosakowski, J. Kuczyńska-Kwapisz, PTP, Olsztyn Poznań - Warszawa 2002. 
Można więc zdecydowanie twierdzić, że nastawienie wobec osób z niepełnosprawnością jest w dużej mierze uzależnione od środowiska społecznego. Jeżeli $\mathrm{w}$ tym środowisku są obecni ludzie $\mathrm{z}$ dysfunkcją, to obcowanie z nimi staje się codziennością, rozwijają się umiejętności wspólnej koegzystencji i postawy wobec nich są najczęściej pozytywne.

Interesujące wydaje się zatem ujawnienie, jakie informacje o osobach $\mathrm{z}$ niepełnosprawnością $\mathrm{w}$ domowych rozmowach przekazują swoim dzieciom kazachscy rodzice, których pociechy uczęszczają do dwóch typów szkół: inkluzyjnej i masowej (ogólnodostępnej). Jest to o tyle ważne, że w Kazachstanie uczniowie z niepełnosprawnością zaledwie od kilku zaledwie lat są obecni w publicznej przestrzeni szkolnej, która do tej pory zarezerwowana była wyłącznie dla uczniów pełnosprawnych. Edukacja włączająca stała się priorytetem polityki oświatowej tego kraju w drugim dziesięcioleciu XXI w. (2011-2020)16.

Warto zauważyć, że kazachska pedagogika zaczęła się intensywnie rozwijać po wyjściu Kazachstanu ze struktur ZSSR w 1991 r. Idea inkluzji edukacyjnej jest popularyzowana od 1999 r., gdy Narodowe Nauko-Praktyczne Centrum Pedagogiki Korekcyjnej w Ałmaty wspólnie z UNESCO rozpoczęło projekt edukacyjny ${ }^{17}$. W roku 2011 pod wpływem pozarządowych organizacji nastąpiła intensyfikacja działań na rzecz edukacji włączającej. Rozpoczęto wtedy akcję „TAK dla edukacji inkluzyjnej” 18 . Społeczne inicjatywy proinkluzyjne wsparte były szeregiem badań teoretycznych, empirycznych i metodycznych podejmowanych na uniwersytetach i w centrach naukowych.

Analiza literatury ujawniła, że naukowcy dużo uwagi poświęcali poznaniu filozofii edukacji inkluzyjnej i jej implantacji poprzez re-

16 Państwowy program rozwoju oświaty Republiki Kazachstanu na lata 2010-2010 Zarządzenie Nr 1118 z dnia 7.12.2010, [Государственная программа развития образования РК на 2011-2020 г2. Приказ №1118 от 07.12.2010], Kazakhstan 2010.

17 G.A. Abayeva [Г.А. Абаева], Специальное образование Республики Казахстан: 20 иет независимости, КазГосЖЕНПУ, Алматы 2012.

18 www.inlcusion.kz [dostęp: 12.05.2017]. 
organizację systemu oświaty Kazachstanu, przygotowanie kadry pedagogicznej, opracowanie strategii włączania ucznia ze specjalnymi potrzebami w proces edukacyjny ${ }^{19}$. Niedawno zainteresowano się także atrakcyjnością społeczną dziecka z niepełnosprawnością ${ }^{20}$. Przegląd dostępnych źródeł kazachsko- i rosyjskojęzycznych (dwa urzędowe języki Kazachstanu) wykazał, że problem społecznej percepcji osób z niepełnosprawnością, a w szczególności wiedzy i zachowań wobec osób z dysfunkcjami przekazywanych przez rodziców w trakcie rozmów z dziećmi, nie był jeszcze opisywany w kazachskiej literaturze. O aktualności badań stanowi więc niedostateczne rozpoznanie nastawień społecznych wobec osób z niepełnosprawnością w Kazachstanie, zaś ważność zagadnienia wynika z założonych celów oświatowych i konieczności kształtowania przyjaznego środowiska szkolnego.

\section{Cel, problemy, metoda, badana grupa}

Zaplanowano pionierskie badania, których głównym przedmiotem było poznanie atrakcyjności społecznej ucznia z niepełnosprawnością ${ }^{21}$. Poznanie treści rozmów kazachskich rodziców dzieci uczęszczających do klas masowych i rodziców dzieci uczących się w klasach inkluzyjnych było jednym z wielu celów tego dużego projektu i zostanie poddane analizie w niniejszym artykule. W szczególności dążono do wyjaśnienia:

${ }^{19}$ G.A Abayeva [Г.А. Абаева], op. cit.; S.M. Kenesbaev i in., Pytania o integracje systemów ksztatcenia w Kazachstanie, "Szkoła Specjalna” 2015, nr 5, 350-360; Z.A. Movkebayeva i in., Metodycheskiye rekomendacyi po podgotovke pedagogom k vnedrenyu inkluzyvnogo obrazovanya, IP „Sagautdinova”, Almaty 2013.

${ }^{20}$ L.A. Butabyeva, Atrakcyjność społeczna rówieśnika z niepetnosprawnościa w wypowiedziach uczniów klas pierwszych kazachskich szkót. Praca doktorska, Biblioteka Akademii Pedagogiki Specjalnej im. Marii Grzegorzewskiej, Warszawa 2016.

21 Ibidem. 
1. Jakie rodzaje niepełnosprawności znają kazachscy rodzice dzieci uczęszczających do szkół ogólnodostępnych (masowych) i inkluzyjnych ${ }^{22}$ ?

2. Jakie są źródła ich wiedzy o osobach z niepełnosprawnością?

3. Czy rozmawiają ze swoimi dziećmi o osobach z niepełnosprawnością i jakie są treści tych rozmów?

4. Czym różni się wiedza i treści rozmów podejmowanych przez rodziców dzieci uczęszczających do szkół inkluzyjnych i rodziców dzieci ze szkół masowych?

Przypuszczano, że kontakt rodziców i ich dzieci z rówieśnikami z niepełnosprawnością sprzyja podejmowaniu rozmów na temat niepełnosprawności i wpływa na treści tych rozmów.

Zastosowano metodę sondażu $\mathrm{z}$ wykorzystaniem techniki ankiety $^{23}$. Kwestionariusz ankiety zawierał pytania zamknięte i otwarte, a w szczególności ${ }^{24}$ :

Pytania zamknięte (TAK - NIE):

1. Czy Pani/Pan zetknął się z problematyką niepełnosprawności?

2. Czy Pani/Pan rozmawia ze swoim dzieckiem na temat osób $\mathrm{z}$ niepełnosprawnością?

Pytania otwarte:

3. Jakie Pani/Pan zna rodzaje niepełnosprawności?

4. Skąd Pani/Pan czerpie informacje o osobach $\mathrm{z}$ niepełnosprawnością?

5. Jeśli Pani/Pan rozmawia ze swoim dzieckiem na temat niepełnosprawności, to jaka jest treść tych rozmów?

Odpowiedzi rodziców na pytania otwarte były transkrybowane i pogrupowane $\mathrm{w}$ odpowiednie kategorie. Analiza materiału ba-

${ }^{22} \mathrm{~W}$ Kazachstanie pod szkołą inkluzyjną rozumiana jest taka placówka, w której są klasy przynajmniej z jednym uczniem z niepełnosprawnością, który (po dostosowaniu metod i środków) realizuje wspólną dla wszystkich uczniów podstawę programową. Dla uczniów, którzy nie są w stanie opanować podstawy programowej, organizuje się klasy korekcyjne.

${ }^{23}$ M. Łobocki, Metody i techniki badań pedagogicznych, Oficyna Wydawnicza „Impuls”, Kraków 2011.

24 Jest to część kwestionariusza. 
dawczego miała charakter jakościowo-ilościowy z wykorzystaniem SPSS25.

Badaniami objęto 102 rodziców narodowości kazachskiej. Respondenci odpowiadali w języku kazachskim. Analizie poddano 50 kwestionariuszy wypełnionych przez rodziców pełnosprawnych uczniów pierwszych klas szkoły inkluzyjnej (grupa inkluzyjna) i 52 kwestionariusze rodziców uczniów pierwszych klas szkoły masowej/ogólnodostępnej (grupa ogólnodostępna). Badania prowadzono pod koniec roku szkolnego 2015/2016.

Terenem eksploracji były dwie duże aglomeracje miejskie Kazachstanu: Astana (stolica od 1997 r.) i Ałmaty (dawna stolica). Opiekunowie zostali pogrupowani według następujących kategorii: matka, ojciec i inni. W badaniach wzięło udział: 72 matki, 22 ojców i 8 innych opiekunów (tabela 1 ). Wiek respondentów mieścił się w przedziale 26-38 lat.

Tabela 1. Liczba opiekunów objętych badaniem z podziałem na grupy inkluzyjną i ogólnodostępną

\begin{tabular}{|c|c|c|c|c|c|}
\hline \multirow{2}{*}{\multicolumn{2}{|c|}{ Grupa }} & \multicolumn{3}{|c|}{ Opiekunowie } & \multirow{3}{*}{$\begin{array}{c}\text { Ogółem } \\
50\end{array}$} \\
\hline & & \multirow{2}{*}{$\begin{array}{c}\text { matka } \\
37\end{array}$} & \multirow{2}{*}{$\begin{array}{c}\text { ojciec } \\
11\end{array}$} & \multirow{2}{*}{$\begin{array}{c}\text { inni } \\
2\end{array}$} & \\
\hline Inl la & Liczebność & & & & \\
\hline Пткіид)d & $\%$ & 74,0 & 22,0 & 4,0 & 100,0 \\
\hline \multirow{2}{*}{ Ogólnodostępna } & Liczebność & 35 & 11 & 6 & 52 \\
\hline & $\%$ & 67,3 & 21,2 & 11,5 & 100,0 \\
\hline \multirow{2}{*}{ Ogółem } & Liczebność & 72 & 22 & 8 & 102 \\
\hline & $\%$ & 70,6 & 21,6 & 7,8 & 100,0 \\
\hline
\end{tabular}

Respondenci legitymowali się wykształceniem zawodowym, średnim i wyższym. Rozkład wykształcenia rodziców grupy ogólnodostępnej przestawiał się następująco: podstawowe - 3 osoby (5,8\%) zawodowe - 19 osób (36,5\%); średnie - 20 badanych (38,5\%);

25 Statistical Package for the Social Sciences - oprogramowanie do statystycznej analizy danych - przyp. red. 
wyższe - 13 osób (21,2,0\%). Natomiast rodzice grupy inkluzyjnej zadeklarowali, że wykształcenie podstawowe mają -2 osoby $(4,0 \%)$, zawodowe - 18 osób (36,0\%); średnie - 20 osób (36,0\%); wyższe 12 osób $(24,0 \%)$. Nie odnotowano różnic istotnych statystycznie pomiędzy grupami ze względu na liczebność, płeć i wykształcenie.

\section{Wyniki badań własnych}

\section{Wiedza kazachskich rodziców o osobach z niepełnosprawnością}

Rodzicom uczniów klas pierwszych rozdano kwestionariusze zawierające pytania o styczność z problematyką niepełnosprawności, znajomość rodzajów niepełnosprawności, źródła informacji i treści rozmów ze swoimi dziećmi na temat niepełnosprawności. Kwestionariusze były wypełniane $\mathrm{w}$ domu.

Zdecydowana większość rodziców (ok. 91\%) twierdziła, że zna osoby z dysfunkcjami lub słyszała o takich osobach i ma na ten temat pewną wiedzę. Takiej odpowiedzi udzielili wszyscy badani grupy inkluzyjnej i zdecydowana większość (82,7\%) grupy ogólnodostępnej. Dziewięcioro rodziców $(17,3 \%)$ dzieci uczących się w szkole masowej nie zetknęło się nigdy z osobami z niepełnosprawnością.

\section{Znajomość rodzajów niepełnosprawności}

Dążono do ujawnienia, jakie rodzaje niepełnosprawności znają rodzice. Odpowiedzi pisemne przyporządkowano typowym rodzajom niepełnosprawności:

- osoby z wadami słuchu,

- osoby z wadami wzroku,

- osoby z zaburzeniami mowy,

- osoby z wadami narządu ruchu,

- osoby z niepełnosprawnością intelektualną.

W tabeli 2. przedstawiono dane dotyczące znajomości rodzajów niepełnosprawności. Rodzice deklarowali, że najbardziej znaną im 
niepełnosprawnością jest dysfunkcja narządu ruchu (69 osób), słuchu (67 osób) oraz wzroku (61 osób), zaś najmniej znaną niepełnosprawność intelektualna (na 102 osoby - 46 odpowiedzi).

Tabela 2. Znajomość rodzajów niepełnosprawności przez rodziców z uwzględnieniem liczby osób

\begin{tabular}{|l|l|l|l|l|l|l|}
\hline \multicolumn{2}{|c|}{ Grupa } & \multicolumn{5}{c|}{ Rodzaj niepełnosprawności } \\
\cline { 3 - 7 } \multicolumn{2}{|c|}{} & słuch & wzrok & mowa & $\begin{array}{c}\text { narząd } \\
\text { ruchu }\end{array}$ & intelekt \\
\hline \multirow{2}{*}{ Inkluzyjna } & Liczba osób & 38 & 32 & 27 & 43 & 18 \\
\cline { 2 - 7 } & $\%$ & 76,0 & 64,0 & 57,4 & 86,0 & 36,0 \\
\hline \multirow{2}{*}{ Ogólnodostępna } & Liczba osób & 29 & 29 & 25 & 26 & 28 \\
\cline { 2 - 7 } & $\%$ & 55,8 & 55,8 & 48,1 & 50,0 & 53,8 \\
\hline \multirow{2}{*}{ Ogółem } & Liczba osób & 67 & 61 & 52 & 69 & 46 \\
\cline { 2 - 7 } & $\%$ & 65,7 & 59,8 & 52,5 & 67,6 & 45,1 \\
\hline
\end{tabular}

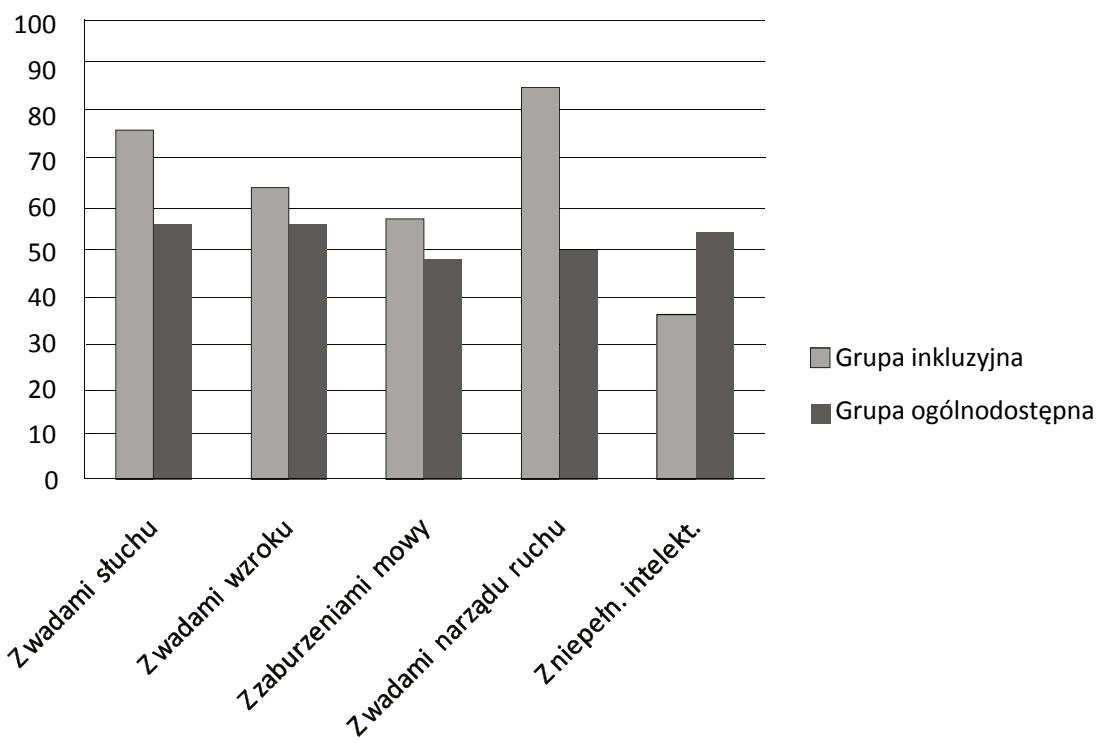

Wykres 1. Rodzaje niepełnosprawności, jakie znają rodzice w podziale na grupy inkluzyjną i ogólnodostępną 
W grupie inkluzyjnej zdecydowana większość respondentów $(86 \%)$ wymieniała wady narządu ruchu, słuchu i wzroku, rzadziej dysfunkcję intelektualną (36\%). Dorośli - podobnie jak ich dzieci26 zwracali uwagę na zewnętrzne oznaki niepełnosprawności.

Rezultaty wskazują, że rodzice uczniów szkoły masowej dzielą się na dwie niemalże równoliczne grupy: na tych którzy dobrze orientują się w różnych typach niepełnosprawności i na tych, którzy nie mają takiego rozpoznania. Respondenci grupy ogólnodostępnej częściej niż grupy inkluzyjnej $w$ swoich ankietach opisywali niepełnosprawność intelektualną (53,8\%) (wykres 1). Część rodziców nie wymieniała $\mathrm{z}$ nazwy niepełnosprawności, zaś wskazywała bezpośrednio na te cechy które, ich zdaniem, charakteryzują niepełnosprawność człowieka, np. brak nogi, ręki. Analiza porównawcza odpowiedzi z zakresu znajomości rodzajów niepełnosprawności ujawniła różnice istotne statystycznie $(\mathrm{p}<0,01)$ na korzyść rodziców grupy inkluzyjnej.

\section{Źródła wiedzy o niepełnosprawności}

Na podstawie pisemnych wypowiedzi wyróżniono pięć źródeł wiedzy o niepełnosprawności: środki masowego przekazu, własne doświadczenia, środowisko rodzinne, środowisko lokalne i edukacyjne. Dla rodziców z grupy inkluzyjnej na pierwszym miejscu jest szkoła, w której pobiera naukę ich dziecko, zaś na drugim mass media. Rodzice grupy ogólnodostępnej na pierwszym miejscu wskazywali mass media, a na drugim własne doświadczenia. Część badanych tej grupy nie potrafiła określić, skąd pochodzi ich wiedza o niepełnosprawności.

${ }^{26}$ L.A. Butabayeva, Atrakcyjność społeczna rówieśnika z niepetnosprawnościa w wypowiedziach uczniów klas pierwszych kazachskich szkót. Praca doktorska, Archiwum Akademii Pedagogiki Specjalnej im. Marii Grzegorzewskiej, Warszawa 2016. 


\section{Treści rozmów rodziców z dziećmi}

Pytano, czy rodzice rozmawiają ze swoimi dziećmi o osobach $\mathrm{z}$ niepełnosprawnością i jakie są treści tych rozmów.

Tabela 3. Liczba rodziców podejmujących z dziećmi rozmowy o niepełnosprawności

\begin{tabular}{|l|l|l|l|c|}
\hline \multicolumn{2}{|c|}{ Grupa } & \multicolumn{2}{c|}{ Rozmowy } & \multirow{2}{*}{ Ogółem } \\
\cline { 3 - 4 } & Tak & Nie & \\
\hline \multirow{2}{*}{ Inkluzyjna } & Liczba osób & 44 & 6 & 50 \\
\cline { 2 - 5 } & $\%$ & 88,0 & 12,0 & 100,0 \\
\hline \multirow{2}{*}{ Ogólnodostępna } & Liczba osób & 30 & 22 & 52 \\
\cline { 2 - 4 } & $\%$ & 57,7 & 42,3 & 100,0 \\
\hline \multirow{2}{*}{ Ogółem } & Liczba osób & 74 & 28 & 102 \\
\cline { 2 - 4 } & $\%$ & 72,5 & 27,5 & 100,0 \\
\hline
\end{tabular}

Ogółem 72,5\% wszystkich badanych odpowiedziało pozytywnie na pytanie o rozmowy z dziećmi na temat niepełnosprawności (tabela 3). Ponad połowa $(57,7 \%)$ rodziców grupy ogólnodostępnej deklarowała podejmowanie $\mathrm{w}$ domu rozmów związanych $\mathrm{z}$ niepełnosprawnością, zaś pozostali (42,3\%) odpowiedzieli negatywnie na to pytanie. Większość respondentów grupy inkluzyjnej (88\%) twierdziła, że rozmawia ze swoją córką/synem głównie o dzieciach z dysfunkcjami, z którymi się uczą.

Pisemne wypowiedzi na temat treści rozmów rodziców z grupy inkluzyjnej układają się w następujące kręgi tematyczne (tabela 4):

1) kształtowanie postawy niekrzywdzącej dziecko niepełnosprawne - 26 osób (52\%). Typowe wypowiedzi: nie krzywdź ich; one sa chore, nie denerwuj ich; nie wolno się z nich śmiać 24 osoby; do nich należy się dobrze odnosić - 2 osoby. Przekaz rodzicielski: toleruj w swoim środowisku, nie dyskryminuj. Kształtowany jest obraz osoby z niepełnosprawnością, która może być krzywdzona, ponieważ jest inna, słaba, chora;

2) kształtowanie postawy zorientowanej na udzielenie pomocy dzieciom z niepełnosprawnością - 12 osób (24\%). Typowe 
wypowiedzi: trzeba im pomóc (5 osób); pomóż im (7osób). Przekaz rodzicielski: bądź gotowy do pomocy i pomagaj, bądź empatyczny. Kształtowany jest obraz osoby niepełnosprawnej potrzebującej pomocy;

3) wzbogacenie wiedzy i kształtowanie obrazu szczególnej osoby i jednocześnie takiej samej - 3 osoby (6\%). Typowe wypowiedzi: To takie same dzieci, jak ty; żeby ich dobrze odbierat. Przekaz rodzicielski: bądź koleżanką, kolegą, jest to twój rówieśnik. Kształtowany jest obraz dziecka wyjątkowego i jednocześnie dziecka takiego samego jak syn czy córka;

4) brak odpowiedzi bądź niepodejmowanie rozmów (18\%).

Tabela 4. Treści rozmów o niepełnosprawności w relacji rodziców z grupy inkluzyjnej

\begin{tabular}{|c|c|c|c|c|}
\hline Lp. & \multicolumn{2}{|c|}{ Kategorie odpowiedzi } & Częstość & $\%$ \\
\hline \multirow{4}{*}{1} & \multirow{4}{*}{$\begin{array}{l}\text { kształtowanie posta- } \\
\text { wy niekrzywdzącej }\end{array}$} & $\begin{array}{l}\text { Nie wolno krzywdzić; } \\
\text { Nie krzywdź ich }\end{array}$ & 21 & 42,0 \\
\hline & & $\begin{array}{l}\text { Do nich należy dobrze się odnosić; } \\
\text { Żeby ich dobrze odbierat }\end{array}$ & 3 & 6,0 \\
\hline & & $\begin{array}{l}\text { Nie wolno się z nich śmiać; } \\
\text { One są chore, nie denerwuj ich }\end{array}$ & 2 & 4,0 \\
\hline & & Ogółem & 26 & 52,0 \\
\hline \multirow{2}{*}{2} & \multirow{2}{*}{$\begin{array}{l}\text { kształtowanie posta- } \\
\text { wy pomocy }\end{array}$} & Pomóż im; Trzeba im pomóc & 12 & 24,0 \\
\hline & & Ogółem & 12 & 24,0 \\
\hline \multirow{4}{*}{3} & \multirow{4}{*}{$\begin{array}{l}\text { wiedza dzieci szcze- } \\
\text { gólne - takie same }\end{array}$} & One są szczególne & 1 & 2,0 \\
\hline & & To takie same dzieci, jak ty & 1 & 2,0 \\
\hline & & Żeby się dowiedziata & 1 & 2,0 \\
\hline & & Ogółem & 3 & 6,0 \\
\hline \multirow{4}{*}{4} & \multirow{4}{*}{$\begin{array}{l}\text { nie podejmowanie } \\
\text { rozmów, inne }\end{array}$} & Brak odpowiedzi & 5 & 10,0 \\
\hline & & Nie wiem, co powiedzieć & 1 & 2,0 \\
\hline & & Niekiedy & 3 & 6,0 \\
\hline & & Ogółem & 9 & 18,0 \\
\hline \multicolumn{3}{|c|}{ Ogółem } & 50 & 100,0 \\
\hline
\end{tabular}


Prawie jedna piąta rodziców grupy inkluzyjnej (9 osób, tj. 18\%) nie wyjawiła tematyki rozmów (brak odpowiedzi - 5 osób, 1 osoba - nie wiem, co powiedzieć, 3 osoby - niekiedy). Należy zauważyć, że sześcioro rodziców (12\%) tej grupy po prostu nie podejmuje rozmów o niepełnosprawności (tabela 4).

Rodzice grupy ogólnodostępnej rozmawiający w domu z dziećmi o osobach z niepełnosprawnością podnoszą kwestie jej dotyczące (tabela 5):

Tabela 5. Treści rozmów o niepełnosprawności w relacji rodziców z grupy ogólnodostępnej

\begin{tabular}{|c|c|c|c|c|}
\hline Lp. & \multicolumn{2}{|c|}{ Kategorie odpowiedzi } & Częstość & $\%$ \\
\hline \multirow{3}{*}{1} & \multirow{3}{*}{$\begin{array}{l}\text { kształtowanie } \\
\text { postawy nie- } \\
\text { krzywdzącej }\end{array}$} & Nie wolno ich krzywdzić & 2 & 3,8 \\
\hline & & Nie wolno szydzić & 2 & 3,8 \\
\hline & & Ogółem & 4 & 7,7 \\
\hline \multirow[t]{2}{*}{2} & \multirow{2}{*}{$\begin{array}{l}\text { kształtowanie } \\
\text { postawy pomocy }\end{array}$} & $\begin{array}{l}\text { Im trzeba pomagać; Żeby dobrze rozu- } \\
\text { miat, pomagat }\end{array}$ & 11 & 21,0 \\
\hline & & Ogółem & 11 & 21,0 \\
\hline \multirow[t]{3}{*}{3} & \multirow{3}{*}{$\begin{array}{l}\text { wiedza (dzieci } \\
\text { szczególne - takie } \\
\text { same) }\end{array}$} & $\begin{array}{l}\text { Powinna wiedzieć; Żeby o nich wie- } \\
\text { dziat; Postaram się wyjaśnić; Żeby sie } \\
\text { nie przestraszyt, kiedy je spotka }\end{array}$ & 5 & 9,8 \\
\hline & & To też sq dzieci & 4 & 7,7 \\
\hline & & Ogółem & 9 & 17,5 \\
\hline \multirow{5}{*}{4} & \multirow{5}{*}{$\begin{array}{l}\text { kształtowanie } \\
\text { obrazu własnego } \\
\text { dziecka }\end{array}$} & Porównuje jego możliwości & 1 & 1,9 \\
\hline & & Doceniat swoje zdrowie & 1 & 1,9 \\
\hline & & Żeby zrozumiat, że jest normalny & 1 & 1,9 \\
\hline & & Żeby doceniat wtasne zdrowie & 1 & 1,9 \\
\hline & & Ogółem & 4 & 7,6 \\
\hline \multirow{5}{*}{5} & \multirow{5}{*}{$\begin{array}{l}\text { niepodejmowanie } \\
\text { rozmów - obawa } \\
\text { przed kontaktem }\end{array}$} & Jest za mały; Jest jeszcze mała & 5 & 9,8 \\
\hline & & Nie pytat; Jeśli zapyta & 3 & 5,7 \\
\hline & & $\begin{array}{l}\text { Nie chcę zmartwić dziecka; Boje się } \\
\text { wystraszyć }\end{array}$ & 2 & 3,8 \\
\hline & & Nie chcę, żeby wiedziała & 1 & 1,9 \\
\hline & & Ogółem & 11 & 21,2 \\
\hline
\end{tabular}


cd. tab. 5

\begin{tabular}{|c|l|l|r|r|}
\hline \multirow{2}{*}{ Lp. } & \multicolumn{2}{|c|}{ Kategorie odpowiedzi } & Częstość & $\%$ \\
\hline \multirow{3}{*}{6} & \multirow{2}{*}{$\begin{array}{l}\text { nie podejmowanie } \\
\text { rozmów - inne }\end{array}$} & Brak odpowiedzi & 12 & 23,1 \\
\cline { 3 - 5 } & Nie wiem, co powiedzié́ & 1 & 1,9 \\
\cline { 2 - 5 } & Ogółem & 13 & 25,0 \\
\hline \multirow{2}{*}{ Ogółem } & 52 & 100,0 \\
\hline
\end{tabular}

1) kształtowania postawy niekrzywdzącej - 4 osoby $(7,7 \%)$. Typowe wypowiedzi: nie trzeba krzywdzić, nie trzeba szydzić;

2) kształtowania postawy zorientowanej na udzielenie pomocy dzieciom - 11 osób (21,0\%). Typowa wypowiedź: trzeba im pomóc;

3) wzbogacenia wiedzy (17,5\%) - 5 osoby i kształtowanie obrazu szczególnej osoby i jednocześnie takiej samej - 4 osoby. Typowe wypowiedzi: żeby o nich wiedziat, to tė̇ sa dzieci;

4) kształtowania obrazu własnego dziecka jako osoby zdrowej, sprawnej, normalnej - 4 osoby (7,6\%). Typowe wypowiedzi: żeby doceniat własne zdrowie, żeby zrozumiat, że jest normalny. Przekaz rodzicielski: ty jesteś normalny - osoba z niepełnosprawnością jest nienormalna, gorsza;

5) niepodejmowanie rozmów ze względu na obawy przed kontaktem - 11 rodziców (21,2\%). Typowe wypowiedzi: Jest za maty, Boję się wystraszyć;

6) niepodejmowanie rozmów - inne (13 osób, 25\%): brak odpowiedzi - 12 osób i Nie wiem, co powiedzieć - 1 osoba.

W grupie ogólnodostępnej w porównaniu z inkluzyjną dwa razy więcej rodziców (24 osoby, tj. 46,2\%) nie rozmawia na temat niepełnosprawności ze swoimi dziećmi (tabela 4., rubryka 5. i 6. łącznie). Połowa $z$ nich nie uzasadnia swojego stanowiska (12 osób). Pozostali zaś uważają, że ich dziecko jest jeszcze za małe (5 osób), aby podejmować takie tematy, ponieważ mogą je tylko wystraszyć (2 osoby). Lepiej więc nie rozmawiać, dopóki nie zapyta (2 osoby). Jedna mama nie chce, aby córka wiedziała cokolwiek na ten temat. $\mathrm{W}$ tabeli 5. odpowiedzi tych rodziców umieszczono w kategorii Obawa przed kontaktem. 
Tabela 6. Wskaźniki analizy statystycznej dotyczącej liczby rodziców podejmujących rozmowy na temat niepełnosprawności $\mathrm{w}$ grupach inkluzyjnej i ogólnodostępnej

\begin{tabular}{|l|c|c|c|c|c|}
\hline \multicolumn{1}{|c|}{ Wskaźniki } & Wartość & $\mathrm{df}$ & $\begin{array}{c}\text { Istotność } \\
\text { asymptotyczna } \\
\text { (dwustronna) }\end{array}$ & $\begin{array}{c}\text { Istotność } \\
\text { dokładna } \\
\text { (dwustronna) }\end{array}$ & $\begin{array}{c}\text { Istotność } \\
\text { dokładna } \\
\text { (jednostronna) }\end{array}$ \\
\hline Chi-kwadrat Pearsona & 11,757 & 1 & 0,001 & - & - \\
\hline Poprawka na ciągłość & 10,284 & 1 & 0,001 & - & - \\
\hline Iloraz wiarygodności & 12,345 & 1 & 0,000 & - & - \\
\hline Dokładny test Fishera & - & - & - & 0,001 & 0,001 \\
\hline Test związku liniowego & 11,642 & 1 & 0,001 & - & - \\
\hline N ważnych obserwacji & 102 & - & - & - & - \\
\hline
\end{tabular}

Analiza porównawcza z wykorzystaniem testów Chi-kwadrat ujawnia, że istotnie większa liczba rodziców grupy inkluzyjnej niż grupy ogólnodostępnej rozmawia ze swoimi dziećmi o niepełnosprawności $(\mathrm{p}<0,01)$ (tabela 6).

$\mathrm{Na}$ podstawie danych kwestionariusza ankiety skierowanej do rodziców kazachskich uczniów pierwszych klas można stwierdzić, że:

1) większość badanych obu grup zetknęła się z zagadnieniem niepełnosprawności;

2) rodzice dzieci uczących się w szkole włączającej lepiej niż rodzice dzieci ze szkoły masowej orientują się w rodzajach niepełnosprawności, różnice są istotne statystycznie na $p<0,01$;

3) rodzice grupy inkluzyjnej informacje w głównej mierze czerpią ze środowiska edukacyjnego swojego dziecka i z mass mediów, zaś rodzice grupy ogólnodostępnej z mass mediów i własnego doświadczenia (praca, ulica, w domu jest osoba z niepełnosprawnością);

4) zdecydowana większość rodziców uczniów szkoły włączającej rozmawia ze swoimi dziećmi na temat niepełnosprawności, różnice $\mathrm{w}$ porównaniu z rodzicami dzieci ze szkoły ogólnodostępnej są istotne statystycznie na $p<0,01$; 
5) rodzice obu grup w domowych rozmowach z dziećmi podnoszą zagadnienia postawy niekrzywdzącej wobec dzieci z niepełnosprawnością (nie krzywdź, oni są tacy sami jak ty) i zachowania empatycznego (pomagaj);

6) rodzice dzieci klas inkluzyjnych zdecydowanie więcej uwagi zwracają na nie dokuczanie, nie krzywdzenie oraz pomaganie rówieśnikom $\mathrm{z}$ niepełnosprawnością niż rodzice dzieci uczęszczających do szkoły masowej;

7) rodzice $z$ grupy ogólnodostępnej w swoich rozmowach bardziej akcentują obawę przed kontaktem z dzieckiem z niepełnosprawnością, które może być odmienne fizycznie i można się go przestraszyć;

8) w pojedynczych przypadkach w grupie ogólnodostępnej odnotowano kształtowanie (zapewne uwarunkowane stereotypami) obrazu osoby z niepełnosprawnością jako nienormalnej, gorszej (np. porównywanie zdolności).

\section{Dyskusja}

Badania wiedzy na temat niepełnosprawności deklarowanej przez kazachskich rodziców dzieci uczących się w szkołach masowej i włączającej wykazały pewne różnice pomiędzy porównywanymi grupami. Okazało się, że rodzice grupy inkluzyjnej ujawnili w tym zakresie lepsze rozpoznanie rodzajów niepełnosprawności. Jako źródło swojej wiedzy wskazywali, oprócz środków masowego przekazu, środowisko edukacyjne swojego dziecka, a więc szkołę włączającą. W świetle polskich badań rodzice dzieci z grup integracyjnych dysponują większą wiedzą na temat niepełnosprawności niż rodzice dzieci z przedszkoli masowych ${ }^{27}$. Dodatkowo stwierdza się większe zainteresowanie rodziców z placówek integracyjnych fachową literaturą i poradami specjalistycznymi ${ }^{28}$. Widoczny zatem

${ }_{27}$ M. Sekułowicz, op. cit.

${ }^{28}$ D. Al-Khamisy, op. cit. 
jest wpływ kontekstu społecznego na poziom wiedzy o niepełnosprawności zarówno kazachskich, jak i polskich rodziców.

Ponad dwie trzecie $(72,5 \%)$ kazachskich rodziców rozmawia w domu ze swoim dzieckiem na temat niepełnosprawności. Aneta Soroka-Fedorczuk ${ }^{29}$ zapytała o to 299 polskich rodziców uczniów masowych i integracyjnych klas pierwszych i trzecich. Odpowiedzi pozytywnej udzieliło ok. $84 \%$ respondentów. Niestety brak jest danych tej autorki z podziałem na grupy uwzględniające typ placówki. Można jednak zauważyć, że zdecydowana większość polskich i kazachskich rodziców podejmuje ze swoim dzieckiem rozmowy o niepełnosprawności. Znacznie częściej zdarza się to jednak w domach dzieci pobierających naukę wspólnie $\mathrm{z}$ niepełnosprawnymi rówieśnikami.

Treści rozmów kazachskich rodzin dotyczą w głównej mierze kształtowania u swojej pociechy postawy niekrzywdzącej, akceptującej dziecko niepełnosprawne oraz gotowości do pomagania. Podobną tematykę rozmów polskich rodziców rejestruje Aneta Soroka-Fedorczuk ${ }^{30}$. Wyniki badań tej autorki ujawniają, że ok. 24\% rozmów związanych jest z udzielaniem pomocy, ok. 20\% dotyczy tolerancyjnej postawy i $12 \%$ prowadzonych rozmów wzbogaca wiedzę o przyczynach niepełnosprawności. W świetle ustaleń Dominiki Przybyszewskiej31 rodzice wybierają placówkę integracyjną dla swoich pełnosprawnych dzieci, kierując się przekonaniami o równości wszystkich, chcą także, aby ich pociechy nauczyły się pomagać innym i traktowały wszystkich w sposób życzliwy. Zatem niezależnie od narodowości i kręgu kulturowego rodzice sądzą, że akceptacja inności i wrażliwość społeczna to bardzo ważne aspekty wspólnego bytowania. Potwierdza się także wpływ czynników eko-

${ }^{29}$ A. Soroka-Fedorczuk, Osoby niepetnosprawne w opiniach dzieci, Oficyna Wydawnicza „Impuls”, Kraków 2007.

30 Ibidem.

${ }^{31}$ D. Przybyszewska, Rodzice uczniów ksztatcacych się w klasach integracyjnych ich oczekiwania i motywy, "Interdyscyplinarne konteksty pedagogiki specjalnej” 2014, nr 6, s. 60. 
logicznych ${ }^{32}$ : im częściej się widuje osoby z niepełnosprawnością, im bliższy jest kontakt, tym większa jest tolerancja i znacznie mniej obaw rodziców o kontakty swojego pełnosprawnego dziecka z rówieśnikiem z niepełnosprawnością.

\section{Podsumowanie}

Przeprowadzone badania pozwoliły poznać deklaracje kazachskich rodziców dotyczące znajomości rodzajów niepełnosprawności, źródeł informacji, treści domowych rozmów z dziećmi. Dla rodziców dzieci ze szkoły inkluzyjnej najważniejszym źródłem wiedzy jest środowisko edukacyjne ich córki lub syna. Rodzice szkoły masowej wiedzę i doświadczenia gromadzą w bezpośrednich i pośrednich kontaktach $\mathrm{z}$ osobami $\mathrm{z}$ niepełnosprawnością w miejscu pracy i środowisku zamieszkania. Wspólnym źródłem informacji o niepełnosprawności rodziców obu grup są mass media (internet i telewizja).

Rodzice uczniów szkoły włączającej wymieniają więcej rodzajów niepełnosprawności niż rodzice uczniów szkoły masowej. Zwłaszcza dobrze orientują się w zakresie niepełnosprawności motorycznej, słuchowej i wzrokowej, bowiem ich dzieci uczęszczają do jednej klasy z uczniami z takimi właśnie niepełnosprawnościami.

Wypowiedzi pisemne rodziców uczniów szkoły masowej świadczą, że zetknęli się z wadami narządu słuchu i wzroku, a także niepełnosprawnością intelektualną. Uczniom z niepełnosprawnością sensoryczną przypisują pewne opóźnienia rozwojowe, które mogą hamować proces nauki w klasie inkluzyjnej33.

32 R. Zaions, Attitudinal effects of mere exposure, "Journal of Personality and Social Psychology" 1968, Vol. 9.

${ }^{33}$ E. M. Kulesza, L. A. Butabayeva, Plusy i minusy edukacji włączajacej w opinii kazachskich rodziców uczniów klas pierwszych, "[Actual Problems of the Correctional Education (pedagogical sciences)]. Aktualni pitannya korekcyjnnoy oswity. Zbirnik naukowyh prac" 2017, Medobori-2006, Kamianiec-Podilskij, Issue 9, vol. 2, s. 85-95. 
Można konstatować, że kazachscy rodzice podejmują rozmowy ze swoimi dziećmi na temat niepełnosprawności, jednak matki i ojcowie dzieci szkoły włączającej poświęcają temu zagadnieniu znacznie więcej uwagi. $W$ rozmowach rodziców dzieci uczęszczających do szkoły masowej, oprócz kształtowania postawy niekrzywdzącej i pomagania, pojawia się wątek budowania obrazu własnego dziecka jako zdrowego i zdolnego w porównywaniu z dzieckiem $\mathrm{z}$ niepełnosprawnością. Jest to niekorzystne zjawisko, bowiem utrwalany i przekazywany jest stereotyp osoby z niepełnosprawnością jako nie tylko „innej”, ale i gorszej. Co piąty rodzic tej grupy ma obawy związane z kontaktem swojego syna/córki z dzieckiem z niepełnosprawnością. $Z$ kolei $w$ rozmowach rodziców dzieci ze szkoły inkluzyjnej dominuje tematyka niekrzywdzenia i pomagania, zaś prawie nieobecne jest budowanie obrazu rówieśnika z niepełnosprawnością po prostu jako dziecka takiego samego jak ich syn czy córka.

$\mathrm{Z}$ analizy wynika, że przekaz rodzicielski w grupie inkluzyjnej bardziej akcentuje postawę tolerancji i niedyskryminowania rówieśnika z niepełnosprawnością niż w grupie ogólnodostępnej. Tu pojawiła się nowa kategoria tematyczna, która ujawnia stereotypowy negatywny obraz osoby z niepełnosprawnością jako osoby „nienormalnej", w oparciu o który kształtowany jest obraz własnego dziecka jako osoby kompletnej, zdrowej, normalnej.

Budowanie inkluzyjnego środowiska to szczytna idea i wielkie wyzwanie dla polityki społeczno-oświatowej każdego państwa. Kazachstan uczynił już widoczne postępy na tym polu, jednak osiągnięcie wytyczonego celu nie jest łatwe, wymaga bowiem nie tylko mądrych decyzji i nakładów finansowych, ale przede wszystkim zmiany społecznego obrazu osoby z niepełnosprawnością.

Bibliografia

Abayeva G.A. [Абаева Г.А.], Спеицальное образование Республики Казахстан: 20 лет независимости, КазГосЖЕНПУ, Алматы 2012.

Al-Khamisy D., Edukacja przedszkolna a integracja społeczna, Wydawnictwo Akademickie „Żak”, Warszawa 2006. 
Banach I., Od integracji do inkluzji, Oficyna Wydawnicza Uniwersytetu Zielonogórskiego, Zielona Góra 2014.

Butabyeva L.A., Atrakcyjność społeczna rówieśnika z niepetnosprawnościa w wypowiedziach uczniów klas pierwszych kazachskich szkót. Praca doktorska, Biblioteka Akademii Pedagogiki Specjalnej im. Marii Grzegorzewskiej, Warszawa 2016.

Stereotypy niepetnosprawności. Między wykluczeniem a integracją, red. M. Chodkowska, S. Byra, Z. Kazanowski, D. Osik-Chudowolska, M. Parachomiuk, B. Szabała, UMCS, Lublin 2010.

Czykwin E., Stygmat społeczny, Wydawnictwo Naukowe PWN, Warszawa 2007.

Durka G., Stereotypy i uprzedzenia wobec osób niepetnosprawnych, [w:] W kręu niepetnosprawności - teoretyczne i praktyczne aspekty poszukiwań w pedagogice specjalnej, red. T. Żółkowska, L. Konopska, Wydawnictwo Uniwersytetu Szczeińskiego, Szczecin 2009.

Chrzanowska I., Pedagogika Specjalna. Od tradycji do wspótczesności, Oficyna Wydawnicza „Impuls”, Kraków 2015.

Jachimczak B., Postawy wobec niepetnosprawności - szansa na społeczna akceptacje, [w:] Pedagogika specjalna - koncepcje i rzeczywistość, red. T. Żółkowska, Print Group, Szczecin 2007.

Kenesbaev S.M. i in., Pytania o integrację systemów ksztatcenia w Kazachstanie, „Szkoła Specjalna" 2015, nr 5.

Kosakowski Cz., Węzłowe problemy pedagogiki specjalnej, Wydawnictwo Akapit, Toruń 2003.

Kulesza E.M., Definiowanie pojęcia osoba niepetnosprawna przez uczniów klas pierwszej i trzeciej szkoły ogólnodostępnej, [w:] Edukacja w warunkach zmiany społecznej i kulturowej, red. E. Skrzetuska, M. Jurewicz, Wydawnictwo SGGW, Warszawa 2016.

Kulesza E.M., Autayeva A.N., Butabyeva L.A., Отношение казахских учащихся первых классов к совместному обучению с ровесниками с ограниченными возможностями здоровья, „Szkoła Specjalna” 2016, LXXVII, nr 4.

Kulesza E.M., Butabayeva L.A., Plusy i minusy edukacji właczajacej w opinii kazachskich rodziców uczniów klas pierwszych, „Aktualni pitannya korekcyjnnoy oswity [Actual Problems of the Correctional Education]. Zbirnik naukowyh prac" 2017, Medobori-2006, Kamianiec-Podilskij, Issue 9, vol. 2.

Łobocki M., Metody i techniki badań pedagogicznych, Oficyna Wydawnicza "Impuls”, Kraków 2011.

Movkebayeva Z.A. i in., Metodycheskiye rekomendacyi po podgotovke pedagogom k vnedrenyu inkluzyvnogo obrazovanya, IP „Sagautdinova”, Almaty 2013.

Ostrowska A. i in., Niepetnosprawni w społeczeństwie 1993-2013, Wydawnictwo IFiSPAN, Warszawa 2015.

Oszustowicz B., Obraz osoby niepetnosprawnej w świadomości dzieci sześcioletnich z przedszkolnej grupy integracyjnej, [w:] Integracja społeczna osób niepetnosprawnych, 
red. G. Dryżałowska, H. Żuraw, Wydawnictwo Akademickie „Żak”, Warszawa 2004.

Olszewski S., Parys K., Trojańska M., Przestrzenie życia osób z niepetnosprawnością. Wydawnictwo Naukowe Uniwersytetu Pedagogicznego, Kraków 2012.

Państwowy program rozwoju oświaty Republiki Kazachstanu na lata 2010-2010 Zarzadzenіе $\mathrm{Nr} 1118$ z dn. 07.12.2010, [Государственная программа развития образования РК на 2011-2020 г2. Приказ №1118 от 07.12.2010], Kazakhstan 2010.

Przybyszewska D., Parents of children studying in integrated classes - their motives and expectations, [w:] Interdyscyplinarne Konteksty Pedagogiki Specjalnej, nr 6, Wydawnictwo Naukowe UAM, Poznań 2014.

Sekułowicz M., Integracja przedszkolna dzieci a postawy rodziców wobec osób niepetnosprawnych, [w:] Pedagogika specjalna szansa na realizacje potrzeb osób niepetnosprawnych, red. W. Dykcik, C. Kosakowski, J. Kuczyńska-Kwapisz, PTP, Olsztyn - Poznań - Warszawa 2002.

Sękowski A., Tendencje integracyjne a postawy wobec osób niepetnosprawnych, [w:] Pedagogika specjalna w reformowanym ustroju edukacyjnym. Materiały z Ogólnopolskiej Konferencji Naukowej, Kazimierz Dolny, 25-26 maja 2000, red. Z. Palak, Wydawnictwo UMCS, Lublin 2001.

Skura M., Postawy nauczycieli szkoty specjalnej wobec osób z niepetnosprawnościa, „Szkoła Specjalna" 2015, nr 1.

Smogorzewska J., Szumski G., Rozwijanie kompetencji społecznych dzieci przedszkolnych. Teoria-Metodyka-Efekty, PWN, Warszawa 2015.

Soroka-Fedorczuk A., Osoby niepetnosprawne w opiniach dzieci, Oficyna Wydawnicza „Impuls”, Kraków 2007.

Tersa K.A., Rola Innego w rozwoju szkoty i nauczyciela. O potencjale tolerancji wobec niepetnosprawnych, [w:] Tolerancja a edukacja, red. M. Patalon, Wydawnictwo Uniwersytetu Gdańskiego, Gdańsk 2008.

Zaions R., Attitudinal effects of mere exposure, "Journal of Personality and Social Psychology" 1968, Vol. 9. 